\begin{tabular}{l|l|l|l} 
Cose Reports in & $\begin{array}{l}\text { Case Rep Neurol 2009;1:8-14 } \\
\text { D01: 10.1159/000215929 }\end{array}$ & Published online: May 9, 2009 & $\begin{array}{l}\text { 2009 S. Karger AG, Basel } \\
\text { ISSN 1662-680X } \\
\text { www.karger.com/crn }\end{array}$ \\
\hline
\end{tabular}

\title{
Transient Automatic Writing Behavior following a Left Inferior Capsular Genu Infarction
}

\author{
Keisuke Suzuki Tomoyuki Miyamoto Masayuki Miyamoto \\ Koichi Hirata
}

Department of Neurology, Dokkyo Medical University, Tochigi, Japan

\section{Key Words}

Capsular genu infarction - Automatic writing behavior · Increased writing activity · Perseveration - Abulia

\begin{abstract}
A 79-year-old, right-handed woman was admitted to the hospital with decreased spontaneity. Brain magnetic resonance imaging showed a left inferior capsular genu infarction. ${ }^{99 m}$ TC-ECD single-photon emission computed tomography revealed a leftdominant diffuse hypoperfusion in the basal ganglia and frontal lobe. The patient showed abulia and increased writing activity without motor or sensory deficit. The writing was mainly perseverative, and words written along lines were legible and without spatial distortions. This augmented writing behavior disappeared on day 21 . The writing characteristic was more similar to automatic writing behavior than hypergraphia. Dissociation between speech and writing behavior was present in our patient. We suggest that a disconnection within the frontal-subcortical circuit contributed to the development of motor perseveration in writing.
\end{abstract}

\section{Introduction}

Increased writing activity is seldom seen in neurological conditions, except in some patients with cerebrovascular disease [1], frontal-type dementia [2], temporal lobe epilepsy [3], and Parkinson's disease [4]. It has never been reported in capsular genu infarction. We report a patient with a left inferior capsular genu infarction who developed abulia and increased writing activity, similar to automatic writing behavior. 


\begin{tabular}{l|l|l|l} 
Cose Reports in & $\begin{array}{l}\text { Case Rep Neurol 2009;1:8-14 } \\
\text { Dol: 10.1159/000215929 }\end{array}$ & & $\begin{array}{l}\text { Published online: May 9, 2009 S. Karger AG, Basel } \\
\text { ISSN 1662-680X } \\
\text { www.karger.com/crn }\end{array}$ \\
\hline
\end{tabular}

\section{Case Report}

The patient was a 79-year-old, right-handed woman who could independently perform daily living activities, including cooking, washing, and cleaning. One day she suddenly lost spontaneous speech, responded to questions with a nod, and remained in bed all day. Two days later, she was admitted to our hospital for evaluation of decreased spontaneity. She had a history of angina, but had no history of psychiatric disease or cognitive impairment. The patient was alert, but indifferent to her surroundings. She showed no signs of motor paresis or sensory deficit. Snout and grasp reflexes were not observed. Focal dystonia was observed in her right hand. Blood levels of ammonia, thyroid hormone, and vitamin $\mathrm{B}_{1}$ were normal. Brain magnetic resonance images (MRI) revealed ischemic lesions involving the inferior genu of the left internal capsule, a part of the internal segment of the globus pallidus, and subcortical white matter with mild cortical atrophy (fig. 1A-C). Diffusion-weighted MRI confirmed that the lesion in the left internal capsule of the genu extended to a part of the internal segment of the globus pallidus, and was responsible for the patient's symptoms (fig. 1D). Magnetic resonance angiography (MRA) showed no occlusions or stenoses in the main cerebral arteries. Technetium-99m ethyl cysteinate dimer single-photon emission computed tomography (SPECT) revealed a left-dominant diffuse hypoperfusion in the basal ganglia and frontal lobe (fig. 1E, F). Electroencephalography findings showed left-dominant theta activity of approximately $7 \mathrm{~Hz}$, without epileptic discharges or triphasic waves.

\section{Neuropsychological Findings}

The patient was not depressed, but showed abulia and amnesia. She scored 7 points on the MiniMental State Examination scale (MMSE). She could follow simple commands without speaking. There was neither apraxia nor agnosia. Visual-spatial testing was normal. The Wechsler Adult Intelligence Scale-Revised and the Trail Making Test were discontinued halfway through the assessment due to decreased spontaneity. Verbal comprehension and naming were mildly impaired, while repetition and reading were preserved. There was no verbal perseveration. Her writing was severely impaired; she could spell only a few words correctly, although when asked to write her name, she exhibited neologism in kanji and wrote 'Ishimura-shinbun', combining 'Ishimura' (her last name) and 'shinbun' (the newspaper placed before her) (fig. 2A). When directions to write her favorite food, hometown, and current date or place were given, she continued to write neologistic kanji words related to her last name. However, after the word 'shinkeinaika' (neurology) was placed in front of her as a written note, she wrote the same word in place of her name and continued writing. The writing was mainly perseverative with lexicographemic alterations; many words written along the lines were legible and without spatial distortions. Increased writing activity was observed when ruled paper and a pen were presented to her; however, this was not observed when blank paper was presented. There was no frustration or anxiety when the pen was removed. She could use other tools such as a toothbrush, scissors, and a comb accurately; utilization behavior was not elicited by presenting those items. She also showed perseveration in drawing figures (fig. 2B). On day 21, when she was asked to write something (her name, her daughter's name, current date or her feelings), she wrote only a few words related to her last name; her increased writing characteristic disappeared completely, except for a slight perseveration. Two years later, her response time to questions had become slightly shorter; however, she replied in a small voice, with a smile, and continued to exhibit decreased spontaneity.

\section{Discussion}

This is the first report of an increased writing activity, together with perseverative writing, that was related to a capsular genu infarction. However, verbal perseveration in patients with capsular genu infarctions has been reported previously, and all patients had left-sided infarctions and showed abulia (table 1) [5-8]. Lai et al. [9] reported a 46-yearold patient with a left capsular genu infarction who exhibited auditory hallucinations and dysgraphia, and whose symptoms predominantly included paraphasia and character error without increased writing activity or perseveration.

Van Vugt et al. [10] reported a 70-year-old right-handed man with a history of alcohol abuse who demonstrated progressive memory disturbance (score of 11 points on the MMSE), verbal aspontaneity, and increased writing activity, which was described as 
'automatic writing behavior'. This diagnosis was based on the perseverative, legible writing pieces of language that he produced both visually and verbally at the syntactic or lexical level, and well-ordered spatial arrangement. On the basis of SPECT findings from right-dominant frontal hypoperfusion, the mechanism was considered to be a particular form of utilization behavior caused by suppression of the inhibitory system of the frontal lobes. In contrast, hypergraphia reportedly comprises large numbers of sentences with copious unrepeated content. The written characters are difficult to read and spatial placement is not ordered [1]. The increased writing activity seen in our patient was more similar to automatic writing behavior than hypergraphia.

Evyapan and Kumral [11] studied automatic writing behavior in three patients with right cerebral hemispheric strokes. They suggested that a combination of visuospatial neglect and frontal dysfunction may be responsible for the mechanism, as all of the patients showed left visuospatial neglect, and writing behavior was elicited only by the visual letters on the right side. In contrast, the neologism in our case of 'Ishimurashinbun' (see fig. 2A) is considered to represent automatic reproduction of the visual stimulus, although our patient did not show visuospatial neglect. In the study by van Vugt et al. [10], the duration of the patient's automatic writing behavior was permanent, while our patient's writing characteristic was temporary and similar to that reported by Evyapan and Kumral [11].

Automatic writing behavior in our patient manifested after the oral or written direction to write, or the presence of ruled paper and a pen. It was probably due to a form of motor perseveration related to the basal ganglia. The pallidum and substantia nigra are the sites of input from motor corticostriatal pathways that interact as part of normal motor control and the termination of movement [12]. Four patients with infarction in the thalamus and the basal ganglia developed motor perseveration of the upper and lower extremities induced by passive movement. One of these patients demonstrated perseveration in drawing figures, which suggests impairment of the prefrontal corticobasal ganglia-thalamocortical loops [13]. In this case, SPECT images revealed diffuse hypoperfusion in the left frontal lobe and basal ganglia, which implies that damage in the anterior and inferior thalamic peduncles, adjacent to the capsular genu, led to thalamocortical disconnection [8] and interruption of the cortico-basal gangliathalamocortical loops [14].

Our patient's repeated writing of her last name may indicate dysfunction of recall and understanding of characters in the dominant hemisphere, which is a requirement for writing [15]. Moreover, a previous study reported that more severe verbal memory loss is caused by lesions on the left side of the capsular genu, compared with lesions on the right [8]. As described in a previous report [11], the transient quality of automatic writing behavior implies possible diaschisis. It remains unclear why other perseverative movements, in addition to writing, did not occur. However, with regard to speech, we assume that the absence of verbal perseveration can partially be attributed to the effect of severe abulia.

Our patient showed focal dystonia in her right hand. We suggest that this may be due to the involvement of a part of the left internal segment of the globus pallidus. Focal dystonia has been thought to be responsible for globus pallidus and thalamic infarction [16].

In our case, the main blood supply route to the capsular genu was undetermined, since cerebral angiography was not performed. However, based on MRA results, our patient did not have occlusions or severe stenoses in the main arteries. It has been reported that 
the capsular genu is supplied by perforating arteries, arising from the apex of the internal carotid or anterior cerebral artery, or by the anterior choroidal artery [17].

The patient was not examined for cognitive or mental function before the onset of the capsular genu infarct; however, we believe that she did not have dementia or psychiatric diseases on admission, since her family attested that before the stroke she had been able to perform her usual activities properly and had showed no personality changes. Moreover, two years after the stroke, the patient showed persistent abulia that did not progress further. Therefore, we suggest that the acute-onset abulia and automatic writing behavior were likely due to the new infarct in the capsular genu (corresponding to high signal intensity on the diffusion-weighted images) rather than concomitant psychiatric or neurodegenerative disorders that exhibited dementia. However, we cannot exclude the possibility that an interaction between a concomitant underlying cognitive dysfunction, due to mild cortical atrophy or subcortical multiple infarcts, and the capsular genu infarct may exist. This may then cause the characteristic writing behavior, since leukoaraiosis has been associated with subtle cognitive impairment [18].

In conclusion, we suggest that malfunction of the frontal-subcortical circuit, due to an inferior capsular genu infarction, contributed to the development of motor perseveration in writing.

\section{Acknowledgement}

We would like to thank Ms. Miyuki Tatsumoto (Department of Neurology, Dokkyo Medical University, Japan) for performing detailed neuropsychiatric examinations of frontal lobe function.

Table 1. Review of perseveration in patients with capsular genu infarction

\begin{tabular}{|c|c|c|c|c|c|c|c|}
\hline Author & Year & $\begin{array}{l}\text { Age/ } \\
\text { gender }\end{array}$ & $\begin{array}{l}\text { Handed- } \\
\text { ness }\end{array}$ & - Lesion site & Abulia & Amnesia & Perseveration \\
\hline Tatemichi et al. [8] & 1992 & $60 / \mathrm{M}$ & $\mathrm{R}$ & left capsular genu & + & + & verbal perseveration \\
\hline Moreaud et al. [7] & 1996 & $23 / \mathrm{M}$ & $\mathrm{R}$ & left capsular genu & + & - & verbal perseveration \\
\hline Chukwudelunzu et al. [5] & 2001 & $71 / \mathrm{F}$ & $\mathrm{R}$ & left capsular genu & + & + & verbal perseveration \\
\hline Hayashi et al. [6] & 2003 & $72 / \mathrm{F}$ & $\mathrm{R}$ & $\begin{array}{l}\text { left capsular genu } \\
\text { and left thalamus }\end{array}$ & + & + & verbal perseveration \\
\hline Present case & 2009 & $79 / \mathrm{F}$ & $\mathrm{R}$ & left capsular genu & + & + & $\begin{array}{l}\text { perseveration in } \\
\text { writing }\end{array}$ \\
\hline
\end{tabular}




\begin{tabular}{l|l|l|l} 
Cose Reports in & $\begin{array}{l}\text { Case Rep Neurol 2009;1:8-14 } \\
\text { D01: 10.1159/000215929 }\end{array}$ & Published online: May 9, 2009 & $\begin{array}{l}\text { (2009 S. Karger AG, Basel } \\
\text { ISSN 1662-680X } \\
\text { www.karger.com/crn }\end{array}$ \\
\hline
\end{tabular}

Fig. 1. A, B T2-weighted axial and coronal magnetic resonance images (MRI; TR/TE, 4,000/100) show that the high-signal lesion involves the left inferior genu and part of the internal segment of the globus pallidus (arrows). C Fluid attenuated inversion recovery images (TR/TE, 8,000/120) showing

periventricular hyperintensities (arrowheads) and multiple lacunar infarctions (arrows). Mild cortical atrophy was noted. D Diffusion weighted MRI (TR/TE, 2,500/82) showing a recent lesion in the genu of the left internal capsule extending to a part of the internal segment of the globus pallidus. $\mathbf{E}, \mathbf{F}$ Technetium-99m ethyl cysteinate dimer ( ${ }^{99 \mathrm{~m}} \mathrm{TC}$-ECD) single-photon emission computed tomography (SPECT) images show diffuse hypoperfusion in the left frontal lobe and basal ganglia (arrows).
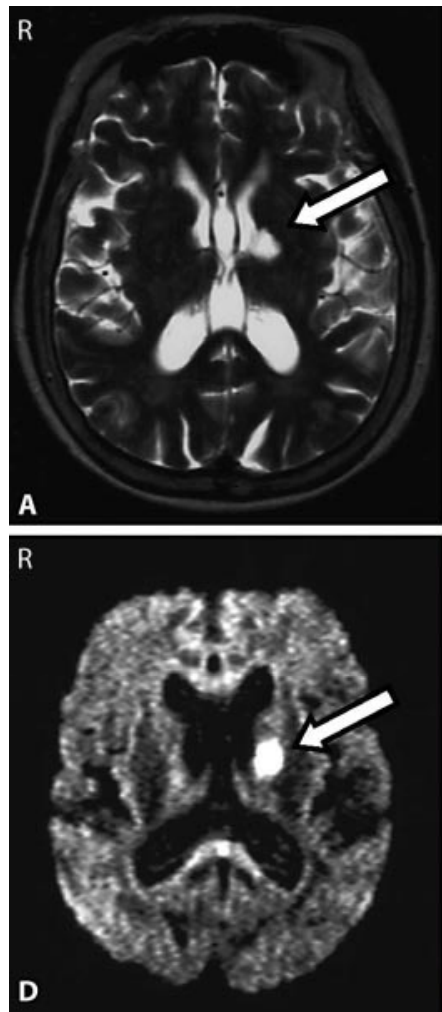
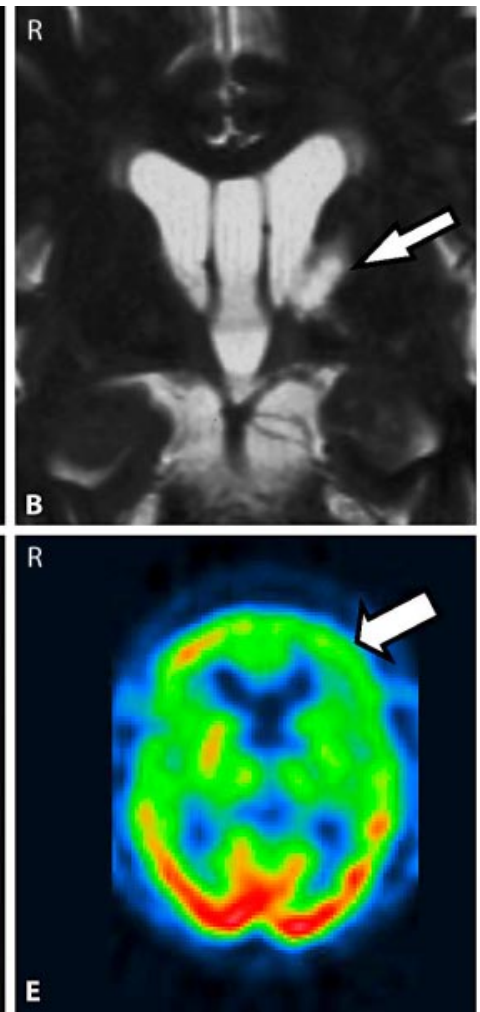
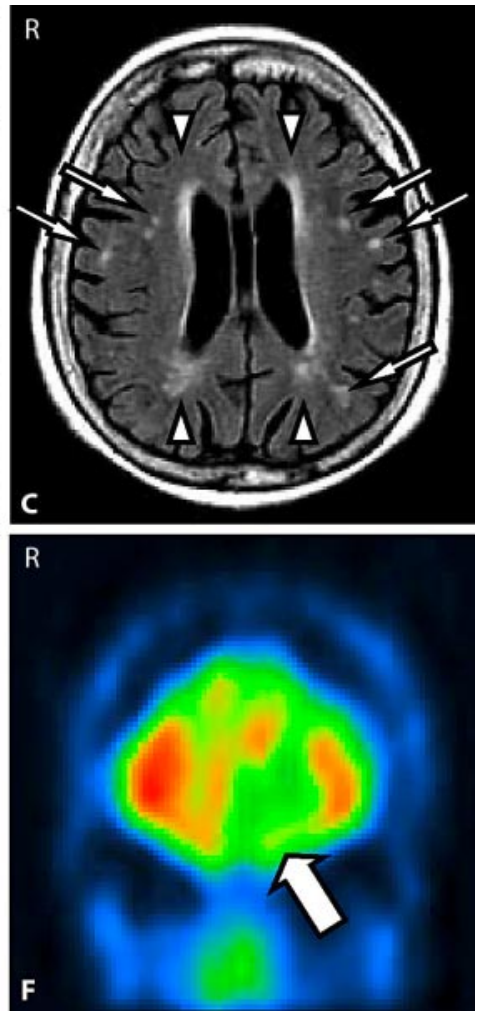


\begin{tabular}{l|l|l|l} 
Cose Reports in & $\begin{array}{l}\text { Case Rep Neurol 2009;1:8-14 } \\
\text { D0l: } 10.1159 / 000215929\end{array}$ & Published online: May 9, 2009 & $\begin{array}{l}\text { @ 2009 S. Karger AG, Basel } \\
\text { ISSN 1662-680X } \\
\text { www.karger.com/crn }\end{array}$ \\
\hline
\end{tabular}

Fig. 2. A The patient continued to write a neologistic kanji (morphograms) word, 'Ishimura-shinbun', which combines 'Ishimura' (her last name) and 'shinbun', which is the name of the newspaper that had been placed before her. Although an additional request was made (to write her birthday and the date at that time), she continued to write similar kanji words, with the following lexicographemic alterations: 'Ishimura-shinbun', 'Ishimura-shinichi', and 'Ishimura-buichi' (arrowhead). However, after the word 'shinkeinaika' (neurology) was placed in front of her in the form of a note (see arrow), the patient wrote 'shinkeinaika' in place of her name and continued writing. B When the figure was placed in front of her in the form of a note (see arrow), the patient continued to draw the same figure.
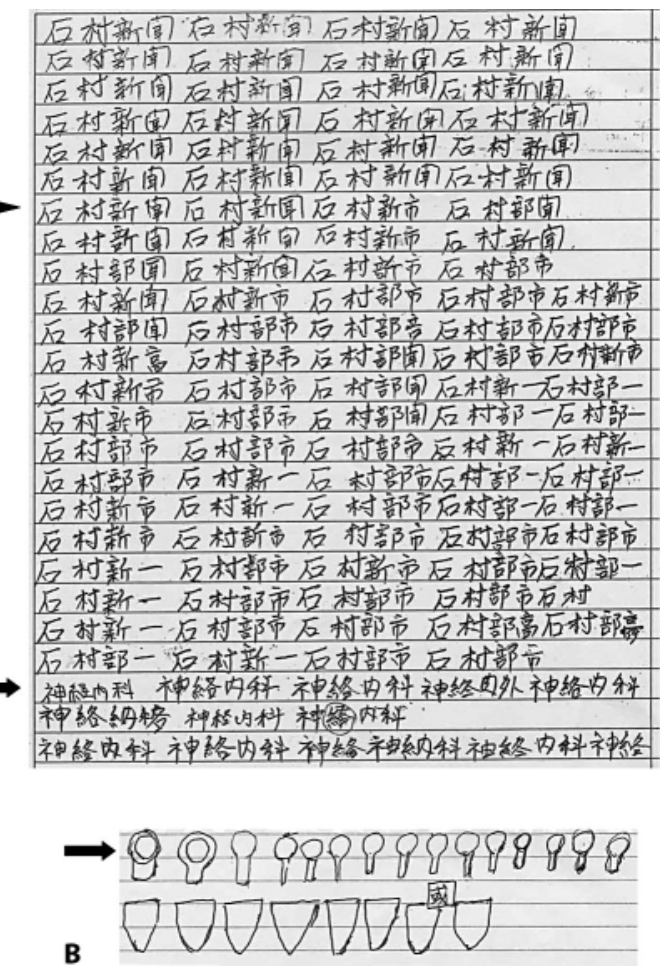


\section{References}

1 Yamadori A, Mori E, Tabuchi M, Kudo Y, Mitani Y: Hypergraphia: A right hemisphere syndrome. J Neurol Neurosurg Psychiatry 1986;49:1160-1164.

2 Frisoni GB, Scuratti A, Bianchetti A, Trabucchi M: Hypergraphia and brain damage. J Neurol Neurosurg Psychiatry 1993;56:576-577.

3 Roberts JK, Robertson MM, Trimble MR: The lateralising significance of hypergraphia in temporal lobe epilepsy. J Neurol Neurosurg Psychiatry 1982;45:131-138.

4 Miwa H, Kondo T: Increased writing activity in Parkinson's disease: a pundinglike behavior? Parkinsonism Relat Disord 2005;11:323-325.

5 Chukwudelunzu FE, Meschia JF, Graff-Radford NR, Lucas JA: Extensive metabolic and neuropsychological abnormalities associated with discrete infarction of the genu of the internal capsule. J Neurol Neurosurg Psychiatry 2001;71:658-662.

6 Hayashi R, Ohashi M, Watanabe R, Mimura M, Katsumata Y: Amnesia, confabulation and nonaphasic misnaming after left thalamic infarct. No To Shinkei 2003;55:530-535.

7 Moreaud O, Charnallet A, David D, Cinotti L, Pellat J: Frontal lobe syndrome after a left genu capsular infarction. Eur Neurol 1996;36:322-324.

8 Tatemichi TK, Desmond DW, Prohovnik I, Cross DT, Gropen TI, Mohr JP, Stern Y: Confusion and memory loss from capsular genu infarction: a thalamocortical disconnection syndrome? Neurology 1992;42:1966-1979.

9 Lai C, Okada Y, Sadoshima S, Saku Y, Kuwabara Y, Fujishima M: A case of left internal capsular infarction with auditory hallucination and peculiar amnesia and dysgraphia. No To Shinkei 1990;42:873-877.

10 van Vugt P, Paquier P, Kees L, Cras P: Increased writing activity in neurological conditions: a review and clinical study. J Neurol Neurosurg Psychiatry 1996;61:510-514.

11 Evyapan D, Kumral E: Visuospatial stimulus-bound automatic writing behavior: a right hemispheric stroke syndrome. Neurology 2001;56:245-247.

12 Marsden CD, Obeso JA: The functions of the basal ganglia and the paradox of stereotaxic surgery in Parkinson's disease. Brain 1994;117(Pt 4):877-897.

13 Fung VS, Morris JG, Leicester J, Soo YS, Davies L: Clonic perseveration following thalamofrontal disconnection: a distinctive movement disorder. Mov Disord 1997; 12:378-385.

14 Cummings JL: Frontal-subcortical circuits and human behavior. Arch Neurol 1993;50:873-880.

15 Lezak MD: Neuropsychological assessment, ed 3. New York, Oxford University Press, 1995.

16 Krystkowiak P, Martinat P, Defebvre L, Pruvo JP, Leys D, Destée A: Dystonia after striatopallidal and thalamic stroke: clinicoradiological correlations and pathophysiological mechanisms. J Neurol Neurosurg Psychiatry 1998;65:703-708.

17 Madureira S, Guerreiro M, Ferro JM: A follow-up study of cognitive impairment due to inferior capsular genu infarction. J Neurol 1999;246:764-769.

18 Schmidt R, Fazekas F, Offenbacher H, Dusek T, Zach E, Reinhart B, Grieshofer P, Freidl W, Eber B, Schumacher M, et al: Neuropsychologic correlates of MRI white matter hyperintensities: a study of 150 normal volunteers. Neurology 1993;43:2490-2494. 